\title{
On Containment Plan Amid COVID- 19 in Red Zone Districts of India: Using Clinical Life Table and Cure Fraction Model
}

\author{
Gurprit Grover', Arpan Kumar Thakur ${ }^{2}$ \\ 1,2Department of Statistics, University of Delhi, Delhi, India. \\ DOI: https://doi.org/10.24321/0019.5138.202039
}

\section{I $\quad \mathbf{N} \quad \mathbf{F} \quad \mathbf{O}$}

\author{
Corresponding Author: \\ Arpan Kumar Thakur, Department of Statistics, \\ University of Delhi, Delhi-110007, India. \\ E-mail Id: \\ arpankmr3@gmail.com \\ Orcid Id: \\ https://orcid.org/0000-0001-7052-8351 \\ How to cite this article: \\ Grover G, Thakur AK. On Containment Plan Amid \\ COVID-19 in Red Zone Districts of India: Using \\ Clinical Life Table and Cure Fraction Model. J \\ Commun Dis 2020; 52(4): 39-48.
}

Date of Submission: 2020-11-10

Date of Acceptance: 2020-12-15

\section{$\begin{array}{llllllll}\mathbf{A} & \mathbf{B} & \mathbf{S} & \mathbf{T} & \mathbf{R} & \mathbf{A} & \mathbf{C} & \mathbf{T}\end{array}$}

Background and Objective: Ministry of Health and Family Welfare, Government of India took many measures to arrest the spread of COVID-19 disease. This research is intended to shed light on number of confirmed cases with respect to population density of the affected districts, to study the proportion of positives among total sample tested, to construct clinical life table of general population w.r.t. number of daily positive cases and to estimate the long-term survivors among general population.

Materials and Methods: Simple scatter plot has been used to see relation between population density and number of cases in different districts of India, cluster analysis technique is used for making cluster of Districts having similar features. Clinical life table is prepared for general population of affected Districts, and mixture \& non-mixture cure fraction models used to estimate the proportion of long-term survivors (disease free survival) of general population.

Result: Median daily proportion of positives are found to be below 0.05 . In 79 identified hot spot Districts average population is very high (36.29 lakhs) with population density of 3404 per square kilometre. Even among those Districts there are huge inter cluster differences w.r.t. number of cases and population density. Clinical life table is constructed for general population of 429 affected Districts, increasing pattern in hazard is found even though study period is small. Long term survivors of disease is simulated and found to be $99.812 \%$.

Conclusion: Government ought to make cluster of Districts among red zone Districts, clustering should be based on number of cases and population density. Different containment strategy may be prepared for each cluster of Districts.

Keywords: COVID-19, Clinical Life Table, Cluster Analysis, Cure Fraction Model 


\section{Introduction}

Whole world is facing the biggest public health crisis of century, the current coronavirus disease came into global discourse on December 31, 2019, the day China notified the World Health Organization about pneumonia of an unknown genesis. Disease first appeared in Wuhan city of Hubei Province of China. The disease spread to more Provinces of China in ensuing days and further to the whole world. The outbreak was declared a Public Health Emergency of International Concern on January 30, 2020. ${ }^{1,2}$

From the daily situation report published by WHO on April 20, 20203, total confirmed cases are 2314621 and total deaths due to COVID-19 are 157847. For the South East Asia region (India, Indonesia, Thailand, Bangladesh, Sri Lanka, Myanmar, Maldives, Nepal, Timor-Leste, Bhutan) total cases till 19 April 2020 are 29576 and total deaths are 1225.

In this region, India alone accounts for $58.37 \%$ of the total cases and $44.32 \%$ of the total deaths. In Indonesia the pandemic has taken community transmission route and all other countries are either on sporadic cases detection phase or on cluster of cases detection phase.

To limit the spread of transmission and death toll Government of India is taking all necessary measures but India being a democratic republic it ought to strike a fine optimal strategy in protecting health, minimizing economic and social unsettling, and respecting human rights.

In India pandemic first set foot in the State of Kerala on January 30, 2020. In very short span of time it is wreaking havoc all over India except for North- Eastern States. Indian Council of Medical Research (ICMR) is spearheading the pandemic management through its various arms spread across the country. It formulates guidelines, coordinates with related government agency/ ministry, promotes research and development of associated treatments and preventions.

The current testing strategy (April 9, 2020) released by ICMR is as follows: All symptomatic individuals who have undertaken international travel in the last 14 days. All symptomatic contacts of laboratory confirmed cases, all symptomatic health care workers. All patients with Severe Acute Respiratory IIIness (fever AND cough and/or shortness of breath), Asymptomatic direct and high-risk contacts of a confirmed case should be tested once between day 5 and day 14 of coming in his/ her contact.

For hotspots area, all symptomatic influenza like illness (fever, cough, sore throat, runny nose) (a). Within 7 days of illness - rRT-PCR, (b). After 7 days of illness - Antibody test (If negative, confirmed by rRT-PCR).

The paper is designed as follows: in the next section 2, various data sources and brief explanation of methods to be used are given. In section 3 results and implications are provided followed by section 4, where final conclusion and insights drawn from research are presented.

\section{Materials and Methods \\ Material}

The data of total number of cases, daily number of tested has been scrapped from crowd sourced website https://www. covid19india.org/, population data from census of India 2011 (http://censusindia.gov.in/) and population density from District of India website (http://districts.nic.in/). To update the population of the Districts to the current time, the annual population growth rate data was used from the published reports of World Bank (https://data.worldbank. org/indicator/SP.POP.GROW? locations=IN). Other sources of COVID-19 data are John Hopkins (https://coronavirus. jhu.edu/), World Health Organization's daily situation report (https://www.who.int/emergencies/diseases/novelcoronavirus-2019/situation-reports). But for this study COVID-19 data only taken from first source.

\section{Method}

Cluster Analysis is a data mining technique where clusters are formed from the objects/observations that belongs to same class. Here similar objects are grouped in one cluster and dissimilar objects are grouped in another cluster, clustering will be performed using $\mathrm{R}$ software package version 3.5.2. Most of times cluster analysis is used as a pre-processing step for other statistical techniques and algorithms. It is applied in marketing, land use study, insurance, city planning, medical imaging etc. ${ }^{5,6}$

\section{Clinical Life Table}

As name suggest this life table technique is used to study the nature of the survival functions, hazard and death density functions of various kinds of survival time data arising in medical research and diagnosis. ${ }^{7-9}$

\section{Mixture Cure Fraction Model}

Let $C$ be the probability of an individual being a long-term survivor and $(1-C)$ be the probability of a patient being infected with COVID-19. Then, Berkson et al. ${ }^{10}$ defined the survival function at any time $t$ as:

$$
S(t)=C+(1-C) * S_{u}(t)
$$

Where, $S u(t)$ is the survival function of the susceptible population which may be assumed to follow some life time distribution. Probability density function $f(t)$ of the overall population is written as:

$f(t)=(1-C) * f u(t)$

Where $f u(t)$ is the probability density function of susceptible population.

Now let $\left(t_{i}, \delta_{i}\right)$ be the observed data of size $n$, where $t_{i}$ is the survival time of the $i^{\text {th }}$ patient and $\delta_{i}$ is censoring indicator variable which is defined as follows: $\delta_{i}=0$ for right-censored observation and $\delta_{i}=1$ for complete observation $(i=1,2, . ., n)$. 
Consequently, the individual's contribution to the likelihood function can be written as:

$$
\begin{aligned}
& L_{i}=\left[f\left(t_{i}\right)\right]^{\delta i}\left[S\left(t_{i}\right)\right]^{(1-\delta i)} \\
& =\left[(1-C) f_{u}\left(t_{i}\right)\right]^{\delta i}\left[C+(1-C) S_{u}\left(t_{i}\right)\right]^{(1-\delta i)}
\end{aligned}
$$

Hence, complete likelihood is given by:

$L=\prod_{i=1}^{n} L_{i}=\prod_{i=1}^{n}\left[(1-C) f_{u}\left(t_{i}\right)\right]^{s}\left[C+(1-C) S_{u}\left(t_{i}\right)\right]^{(1-\delta)}$

Parameters can be estimated by maximizing the complete data likelihood in equation (4) using Open BUGS software package using Gibbs sampling approach. ${ }^{11-18}$

\section{Non-Mixture Cure Rate Model}

In order to accommodate the changes (like second and third wave of disease that reduces event free survival that may occur during the study, a non-mixture cure rate models can be used. It is defined as:

$$
\mathrm{S}(\mathrm{t})=\exp \left[(\ln \mathrm{C})^{*} \mathrm{~F}_{\mathrm{u}}(\mathrm{t})\right]
$$

Where ' $C$ ' is the probability of an Individual being long-term survivor and $F u(t)=1-S u(t)$ is the distribution function for susceptible individual.

In the model $(5), \mathrm{i}^{\text {th }}(\mathrm{i}=1,2, \ldots, \mathrm{n})$ individual's contribution in the likelihood function can be written as:

$$
L i=\left[h\left(t_{i}\right)\right]^{\delta i}\left[S\left(t_{i}\right)\right]=\left[-(\ln C) f u\left(t_{i}\right)\right]^{\delta i} \exp \left[(\ln C) * F u\left(t_{i}\right)\right]
$$

Hence, complete data likelihood is given by:

$L=\Pi L i=\Pi\left[-(\ln C) f u\left(t_{i}\right)\right]^{\delta i} \exp \left[(\ln C) * F u\left(t_{i}\right)\right]$ here product if from $\mathrm{i}=1$ to $\mathrm{n}$ parameters of the above two models will be estimated by Gibbs sampling in the Bayesian framework. ${ }^{19}$

\section{Result}

Table 1, presents the country data obtained from crowd sourced data repository that take feed from various updates published by ICMR on almost real time basis. Daily proportion of positives is calculated as daily positives/daily tested, Figure 1 shows the simple bar plot of daily number of tested and daily number of positives. Due to some discrepancy in observation and unavailability of data only up to 19 April 2020 cases are taken.

Figure 1, gives the line plot of daily proportion of positives, it is observed that on $10^{\text {th }}$ April and on $18^{\text {th }}$ proportion of positive are 0.07107 and 0.06127 respectively. For remaining 17 days of observation proportion of positives are in the band of 0.03 to 0.06 . Two period moving averages smooths the spikes on those two days and shrinks it to band of 0.03 to 0.06 . On performing Wilcoxon signed rank test on proportion of positives with null Hypothesis $\left(\mathrm{H}_{0}\right)$ : The median proportion of positive is equal to 0.05 per day versus alternate Hypothesis $\left(\mathrm{H}_{1}\right)$ : The median proportion of positive is less than 0.05 per day. At $95 \%$ level of confidence null hypothesis get rejected so the median daily proportion of positive is less than 0.05 . So, on an around $50 \%$ of the days, proportion of positives are less than 0.05 .

Table I.Testing status from April I to April 19, 2020

\begin{tabular}{|c|c|c|c|c|c|}
\hline Date & Cumulative tested & Cumulative positives & Daily tested & Daily positives & Daily proportion of positives \\
\hline 1. & 47951 & 1637 & 5000 & 234 & 0.04680 \\
\hline 2. & 55851 & 2056 & 7900 & 419 & 0.05304 \\
\hline 3. & 69245 & 2653 & 13394 & 597 & 0.04457 \\
\hline 4. & 79950 & 3113 & 10705 & 460 & 0.04297 \\
\hline 5. & 89534 & 3554 & 9584 & 441 & 0.04601 \\
\hline 6. & 101068 & 4135 & 11534 & 581 & 0.05037 \\
\hline 7. & 114015 & 4616 & 12947 & 481 & 0.03715 \\
\hline 8. & 127919 & 5114 & 13904 & 498 & 0.03582 \\
\hline 9. & 144910 & 5705 & 16991 & 591 & 0.03478 \\
\hline 10. & 161330 & 6872 & 16420 & 1167 & 0.07107 \\
\hline 11. & 179374 & 7703 & 18044 & 831 & 0.04605 \\
\hline 12. & 195748 & 8312 & 16374 & 609 & 0.03719 \\
\hline 13. & 217554 & 9341 & 21806 & 1029 & 0.04719 \\
\hline 14. & 244893 & 10307 & 27339 & 966 & 0.03533 \\
\hline 15. & 274599 & 11297 & 29706 & 990 & 0.03333 \\
\hline 16. & 302956 & 12581 & 28357 & 1284 & 0.04528 \\
\hline 17. & 335123 & 14098 & 32167 & 1517 & 0.04716 \\
\hline 18. & 372123 & 16365 & 37000 & 2267 & 0.06127 \\
\hline 19. & 401586 & 17615 & 29463 & 1250 & 0.04243 \\
\hline
\end{tabular}




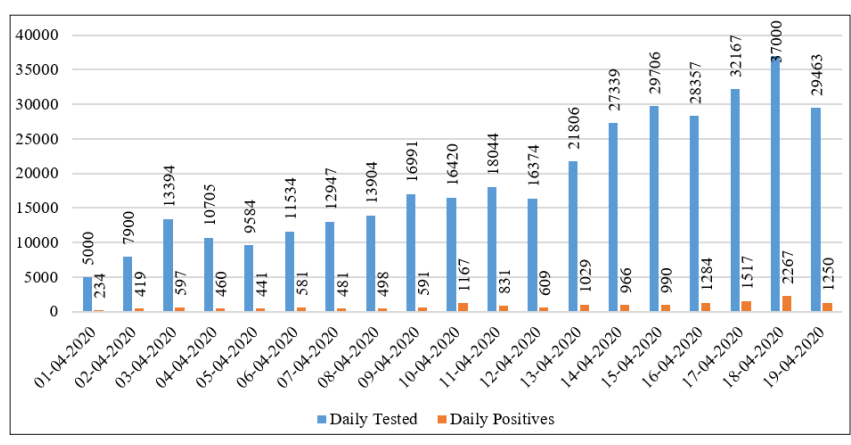

Figure I.Day wise number of tests performed and positive cases

The total number of districts affected by this pandemic is 429 (as per the Ministry of Health 22 April 2020). These districts houses the whooping 106.5 Crores population (with base population taken from census 2011, Govt. of India and yearly average population growth taken from World Bank data to estimate the each district's current population). If we take current population of India as 135 Crores (approx.) then around $78.88 \%$ of the population are exposed to the risk of COVID-19. Average population of these 429 Districts are 2351506 (23.5 Lakhs) with population density of 1358 per square kilometre.

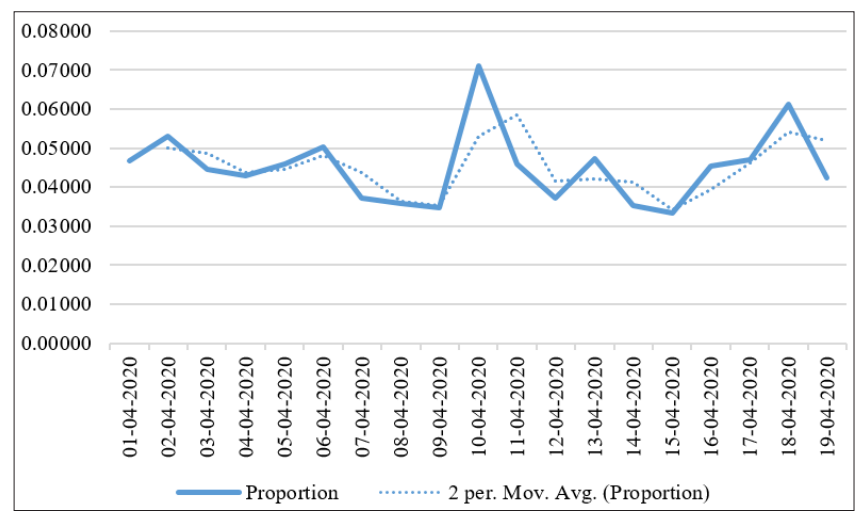

Figure 2.Daily proportion of positives

Fortunately, not all 429 Districts are equally infected. As per the guidelines of the Ministry of Health and Family Welfare about segregating Districts in Red (Hot Spot), Yellow and Green Zones, red zones Districts are those with highest caseload contributing to over $80 \%$ of the total cases in India. By applying the said criteria the following 79 out of 429 affected Districts contributes to over $80 \%$ of the total cases (Table 2).

In these 79 Districts, total number of cases are 13844 which is over $80 \%$ of the total positive cases 17246 . For the above Districts average population is 3629037 (36.29 Lakhs) which was only 23.5 Lakhs for 429 Districts combined. Similarly population density is $3404 /(\mathrm{km})^{2}$ for red zone districts which was only $1358 /(\mathrm{km})^{2}$ for 429 Districts combined. So, there is high risk of spreading of disease in these hot spot Districts as compared to Districts that currently falls in yellow and green zones. One obvious reason for this is, the fact that till date COVID-19 only affected the urban agglomeration where population densities are highest.

Table 2.Name of district (number of positive cases)

\begin{tabular}{|c|c|c|c|}
\hline $\begin{array}{c}\text { Mumbai } \\
\text { (3029) }\end{array}$ & $\begin{array}{l}\text { Guntur } \\
(128)\end{array}$ & $\begin{array}{l}\text { South Delhi } \\
\text { (70) }\end{array}$ & $\begin{array}{c}\text { Bhubaneswar } \\
\text { (46) }\end{array}$ \\
\hline $\begin{array}{l}\text { Ahme- } \\
\text { dabad } \\
\text { (1298) }\end{array}$ & $\begin{array}{l}\text { West } \\
\text { Delhi } \\
(122)\end{array}$ & Erode (70) & Madurai (46) \\
\hline $\begin{array}{l}\text { Indore } \\
(915)\end{array}$ & $\begin{array}{c}\text { Tiruppur } \\
\text { (109) }\end{array}$ & Nellore (67) & $\begin{array}{c}\text { Thanjavur } \\
\text { (46) }\end{array}$ \\
\hline Pune (660) & $\begin{array}{c}\text { Bharatpur } \\
(102)\end{array}$ & & $\begin{array}{c}\text { North } 24 \\
\text { Parganas (46) } \\
\end{array}$ \\
\hline Jaipur (537) & Kota (99) & $\begin{array}{c}\text { Tirunelveli } \\
\text { (62) }\end{array}$ & Prakasam (44) \\
\hline $\begin{array}{c}\text { Hyderabad } \\
(472)\end{array}$ & $\begin{array}{c}\text { G.B. } \\
\text { Nagar (98) }\end{array}$ & $\begin{array}{c}\text { Sasnagar } \\
(61)\end{array}$ & $\begin{array}{c}\text { Nagapattinam } \\
(44)\end{array}$ \\
\hline Thane (465) & $\begin{array}{c}\text { Nashik } \\
(96)\end{array}$ & $\begin{array}{l}\text { North Delhi } \\
(60)\end{array}$ & $\begin{array}{c}\text { Baramulla } \\
\text { (43) }\end{array}$ \\
\hline Surat (338) & Tonk (95) & $\begin{array}{c}\text { Banswara } \\
(60)\end{array}$ & Theni (43) \\
\hline $\begin{array}{l}\text { Chennai } \\
\text { (303) }\end{array}$ & $\begin{array}{l}\text { Kannur } \\
\text { (92) }\end{array}$ & Kanpur (59) & $\begin{array}{l}\text { South West } \\
\text { Delhi (42) }\end{array}$ \\
\hline $\begin{array}{l}\text { Bhopal } \\
(277)\end{array}$ & $\begin{array}{c}\text { Bengaluru } \\
\text { (89) }\end{array}$ & Nagpur (58) & Faridabad (42) \\
\hline Agra (241) & & $\begin{array}{c}\text { Firozabad } \\
(58)\end{array}$ & Belagavi (42) \\
\hline $\begin{array}{l}\text { Jodhpur } \\
\text { (228) }\end{array}$ & $\begin{array}{c}\text { Bandipora } \\
(81)\end{array}$ & $\begin{array}{c}\text { Moradabad } \\
\quad(58) \\
\end{array}$ & Karur (42) \\
\hline $\begin{array}{l}\text { Vadodara } \\
\text { (188) }\end{array}$ & $\begin{array}{c}\text { Srinagar } \\
(79)\end{array}$ & Nuh (57) & Dhaar (41) \\
\hline $\begin{array}{c}\text { Central } \\
\text { Delhi (184) }\end{array}$ & $\begin{array}{l}\text { Howrah } \\
(79)\end{array}$ & $\begin{array}{c}\text { Nizamabad } \\
(56)\end{array}$ & Khargon (41) \\
\hline $\begin{array}{c}\text { Kolkata } \\
(170)\end{array}$ & $\begin{array}{c}\text { Krishna } \\
(76)\end{array}$ & $\begin{array}{l}\text { Cheng- } \\
\text { alpattu (53) }\end{array}$ & $\begin{array}{c}\text { Ghaziabad } \\
(41)\end{array}$ \\
\hline $\begin{array}{l}\text { Kasaragode } \\
\text { (170) }\end{array}$ & $\begin{array}{c}\text { Nagpur } \\
(76)\end{array}$ & $\begin{array}{c}\text { Namakkal } \\
(50)\end{array}$ & Rajkot (40) \\
\hline $\begin{array}{l}\text { Lucknow } \\
\text { (167) }\end{array}$ & $\begin{array}{l}\text { Dindigul } \\
(76)\end{array}$ & $\begin{array}{c}\text { Tiruch- } \\
\text { irapalli (50) }\end{array}$ & Ranipet (39) \\
\hline $\begin{array}{c}\text { Kurnool } \\
(158)\end{array}$ & $\begin{array}{c}\text { Suryapet } \\
\text { (75) }\end{array}$ & $\begin{array}{c}\text { Shahadara } \\
\text { (48) }\end{array}$ & East Delhi (38) \\
\hline $\begin{array}{c}\text { Coimbatore } \\
\text { (133) }\end{array}$ & $\begin{array}{c}\text { Meerut } \\
(75)\end{array}$ & $\begin{array}{c}\text { Jalandhar } \\
(48)\end{array}$ & Gurgaon (38) \\
\hline $\begin{array}{l}\text { South East } \\
\text { Delhi (130) }\end{array}$ & $\begin{array}{c}\text { Sahar- } \\
\text { anpur (72) }\end{array}$ & $\begin{array}{l}\text { Thiruvallur } \\
\text { (48) }\end{array}$ & \\
\hline
\end{tabular}




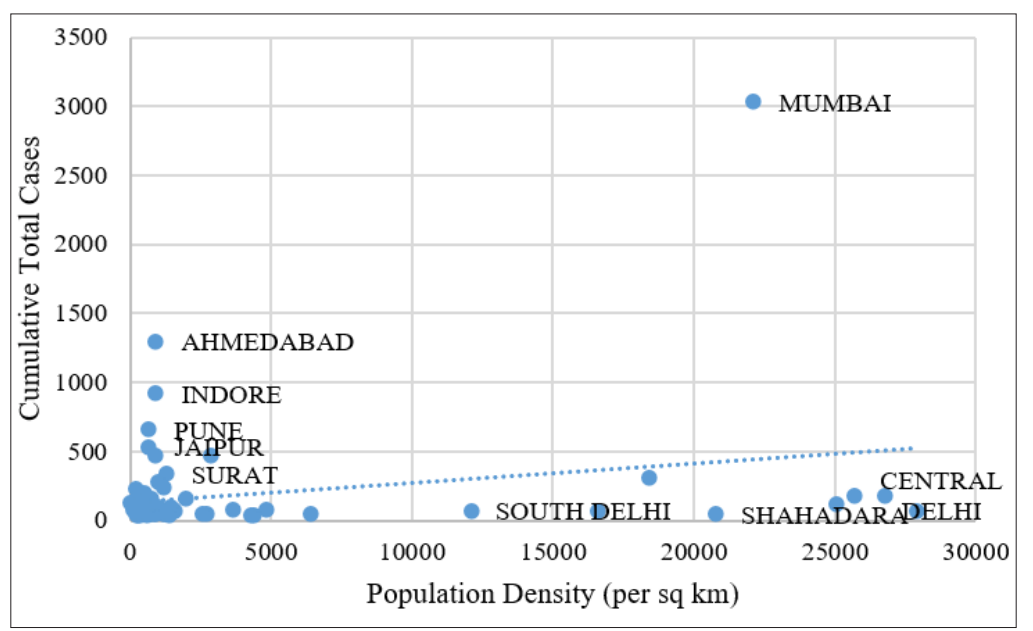

Figure 3.Scatter plot of population density and number of cases in hot spot districts

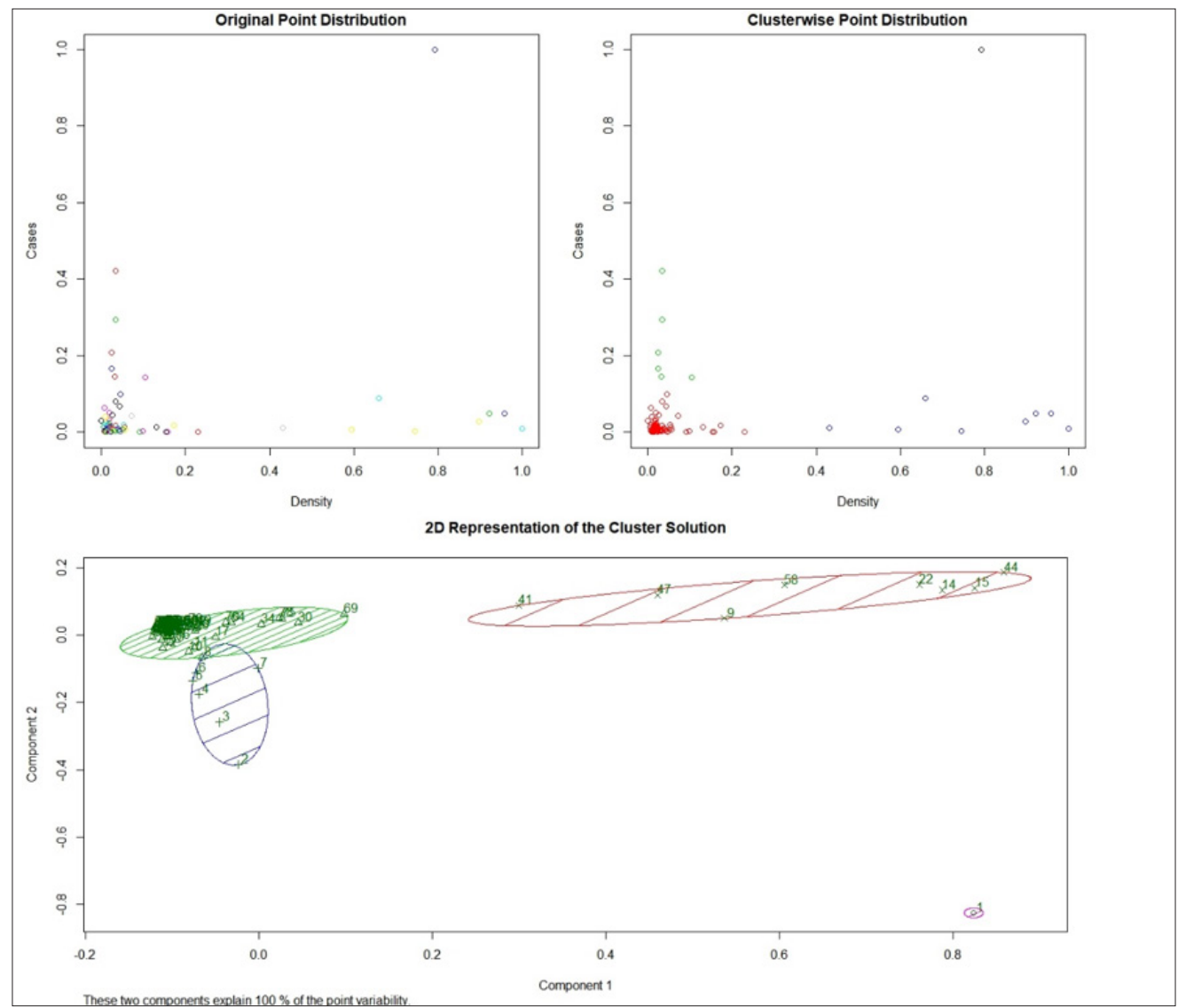

Figure 4. Cluster of districts based on total cases and population density

For 79 hot spot Districts correlation between population density and number of cases 0.2166 (and is significant at $10 \%$ confidence level). Figure 3 gives the simple scatter plot between population density and cumulative cases in 79 identified hot spot Districts. By visually inspecting the graph, one may get the rough idea about similarities between Districts with respect to density and cases.

In order to make cluster of Districts, a normalization of variable is performed (to change the values of numeric variable into a common scale). $\mathrm{K}$ means clustering algorithm has been employed to accomplish the cluster-making task. Graph (Figure 4) at top left shows the original point distribution on normalized values, top right graph shows the cluster wise point distribution. Graph at bottom depicts the four cluster solution in 2-dimension. Table 3, presents the name of Districts that falls in different clusters along with average number of cases and population density of each cluster. 
Table 3.Name of districts in each cluster

\begin{tabular}{|c|c|c|c|}
\hline Cluster & Districts & $\begin{array}{l}\text { Average } \\
\text { number } \\
\text { of cases }\end{array}$ & $\begin{array}{c}\text { Average } \\
\text { density } \\
\text { (square km) }\end{array}$ \\
\hline Cluster 1 & Mumbai & 3029 & 22113 \\
\hline \multirow{6}{*}{ Cluster 3} & Ahmedabad & \multirow{6}{*}{724.5} & \multirow{6}{*}{1156.33} \\
\hline & Indore & & \\
\hline & Pune & & \\
\hline & Jaipur & & \\
\hline & Hyderabad & & \\
\hline & Thane & & \\
\hline \multirow{8}{*}{ Cluster 4} & Chennai & \multirow{8}{*}{129.75} & \multirow{8}{*}{21659.125} \\
\hline & Central Delhi & & \\
\hline & Kolkata & & \\
\hline & West Delhi & & \\
\hline & South Delhi & & \\
\hline & Mumbai Sub Ur & & \\
\hline & North Delhi & & \\
\hline & Shahadara & & \\
\hline Cluster 2 & $\begin{array}{c}\text { All remaining } 64 \\
\text { Districts }\end{array}$ & 84.84 & 1041.06 \\
\hline
\end{tabular}

On close examination of clusters it is observed that cluster 4 which now has average number of positive cases of
129.75 (which seems quite low as compared to cluster 1 and cluster 3) but that cluster has very high average population density of 21659.12 per square kilometre, which is alarming, as higher the population density there is higher risk of disease proliferation.

Table 4, gives clinical life table with starting population of 1006444833. Starting population is obtained from total combined population of 429 affected districts and is treated as number of people exposed to risk of contacting COVID-19 during study period. Various columns of life table are as follows: $d_{i}=$ daily positive cases, $n_{i}=$ number exposed to the risk of contacting COVID-19 (in this case it is total population of disease affected Districts), conditional proportion of infection $\left(q_{i}\right)$ is defined as $d_{i} / n_{i}$, conditional proportion of surviving $\left(p_{i}\right)$ is as $\left(1-q_{i}\right)$, cumulative proportion surviving $\left[S\left(t_{i}\right)\right]=p_{i-1} S\left(t_{i-1}\right)$ with $S\left(t_{1}\right)=1$. Estimated probability density function $f\left(t_{j}\right)=q_{i} S\left(t_{i}\right)$ which is probability of getting infected in $\mathrm{i}^{\text {th }}$ day, hazard function $\left.\left[h\left(t_{i}\right)\right]=q_{i} /\left(1+p_{i}\right)\right)$ which is the number of infections per unit time in the interval divided by average number of survivors at mid-point of interval. Cumulative hazard $[\mathrm{H}(\mathrm{t})]$ is simply the cumulative sum of hazard $[h(t)]$.

Figure 5, shows the survival function plotting, clearly the slope is in downward direction. Although, decrement is quite small but when one think in terms of general population it will give significant number of infected persons in short lap of time. Figure 6 and 7 gives the hazard and cumulative hazard plotting of general population.

Table 4.Clinical life table

\begin{tabular}{|l|c|c|c|c|c|c|c|c|c|}
\hline Date & $\begin{array}{c}\text { Mid- } \\
\text { point }\end{array}$ & $\begin{array}{c}\mathbf{D} \text { (Posit- } \\
\text { ives) }\end{array}$ & $\mathbf{n}_{\mathbf{i}}$ & $\mathbf{q}_{\mathbf{i}}$ & $\mathbf{p}_{\mathbf{i}}$ & $\mathbf{S}(\mathbf{t})$ & $\mathbf{f}(\mathbf{t})$ & $\mathbf{h}(\mathbf{t})$ & $\mathbf{H}(\mathbf{t})$ \\
\hline 01-Apr & 0.5 & 234 & 1006444833 & $\begin{array}{c}2.32502 \\
\mathrm{E}-07\end{array}$ & 0.999999767 & 1 & $\begin{array}{c}2.32502 \\
\mathrm{E}-07\end{array}$ & $\begin{array}{c}2.32502 \\
\mathrm{E}-07\end{array}$ & $\begin{array}{c}2.32502 \\
\mathrm{E}-07\end{array}$ \\
\hline 02-Apr & 1.5 & 419 & 1006444599 & $\begin{array}{c}4.16317 \\
\mathrm{E}-07\end{array}$ & 0.999999584 & 0.999999767 & $\begin{array}{c}4.16317 \\
\mathrm{E}-07\end{array}$ & $\begin{array}{c}4.16317 \\
\mathrm{E}-07\end{array}$ & $\begin{array}{c}6.48819 \\
\mathrm{E}-07\end{array}$ \\
\hline 03-Apr & 2.5 & 597 & 1006444180 & $\begin{array}{c}5.93177 \\
\mathrm{E}-07\end{array}$ & 0.999999407 & 0.999999351 & $\begin{array}{c}5.93177 \\
\mathrm{E}-07\end{array}$ & $\begin{array}{c}5.93178 \\
\mathrm{E}-07\end{array}$ & $\begin{array}{c}1.242 \\
\mathrm{E}-06\end{array}$ \\
\hline 04-Apr & 3.5 & 460 & 1006443583 & $\begin{array}{c}4.57055 \\
\mathrm{E}-07\end{array}$ & 0.999999543 & 0.999998758 & $\begin{array}{c}4.57054 \\
\mathrm{E}-07\end{array}$ & $\begin{array}{c}4.57055 \\
\mathrm{E}-07\end{array}$ & $\begin{array}{c}1.69905 \\
\mathrm{E}-06\end{array}$ \\
\hline 05-Apr & 4.5 & 441 & 1006443123 & $\begin{array}{c}4.38177 \\
\mathrm{E}-07\end{array}$ & 0.999999562 & 0.999998301 & $\begin{array}{c}4.38176 \\
\mathrm{E}-07\end{array}$ & $\begin{array}{c}4.38177 \\
\mathrm{E}-07\end{array}$ & $\begin{array}{c}2.13723 \\
\mathrm{E}-06\end{array}$ \\
\hline 06-Apr & 5.5 & 581 & 1006442682 & $\begin{array}{c}5.77281 \\
\mathrm{E}-07\end{array}$ & 0.999999423 & 0.999997863 & $\begin{array}{c}5.7728 \\
\mathrm{E}-07\end{array}$ & $\begin{array}{c}5.77281 \\
\mathrm{E}-07\end{array}$ & $\begin{array}{c}2.71451 \\
\mathrm{E}-06\end{array}$ \\
\hline 07-Apr & 6.5 & 481 & 1006442101 & $\begin{array}{c}4.77921 \\
\mathrm{E}-07\end{array}$ & 0.999999522 & 0.999997285 & $\begin{array}{c}4.7792 \\
\mathrm{E}-07\end{array}$ & $\begin{array}{c}4.77921 \\
\mathrm{E}-07\end{array}$ & $\begin{array}{c}3.19243 \\
\mathrm{E}-06\end{array}$ \\
\hline 08-Apr & 7.5 & 498 & 1006441620 & $\begin{array}{c}4.94813 \\
\mathrm{E}-07\end{array}$ & 0.999999505 & 0.999996808 & $\begin{array}{c}4.94811 \\
\mathrm{E}-07\end{array}$ & $\begin{array}{c}4.94813 \\
\mathrm{E}-07\end{array}$ & $\begin{array}{c}3.68724 \\
\mathrm{E}-06\end{array}$ \\
\hline 09-Apr & 8.5 & 591 & 1006441122 & $\begin{array}{c}5.87218 \\
\mathrm{E}-07\end{array}$ & 0.999999413 & 0.999996313 & $\begin{array}{c}5.87215 \\
\mathrm{E}-07\end{array}$ & $\begin{array}{c}5.87218 \\
\mathrm{E}-07\end{array}$ & $\begin{array}{c}4.27446 \\
\mathrm{E}-06\end{array}$ \\
\hline
\end{tabular}




\begin{tabular}{|l|c|c|c|c|c|c|c|c|c|}
\hline $10-A p r$ & 9.5 & 1167 & 1006440531 & $\begin{array}{c}1.15953 \\
\mathrm{E}-06\end{array}$ & 0.99999884 & 0.999995726 & $\begin{array}{c}1.15953 \\
\mathrm{E}-06\end{array}$ & $\begin{array}{c}1.15953 \\
\mathrm{E}-06\end{array}$ & $\begin{array}{c}5.43399 \\
\mathrm{E}-06\end{array}$ \\
\hline 11-Apr & 10.5 & 831 & 1006439364 & $\begin{array}{c}8.25683 \\
\mathrm{E}-07\end{array}$ & 0.999999174 & 0.999994566 & $\begin{array}{c}8.25679 \\
\mathrm{E}-07\end{array}$ & $\begin{array}{c}8.25683 \\
\mathrm{E}-07\end{array}$ & $\begin{array}{c}6.25968 \\
\mathrm{E}-06\end{array}$ \\
\hline $12-\mathrm{Apr}$ & 11.5 & 609 & 1006438533 & $\begin{array}{c}6.05104 \\
\mathrm{E}-07\end{array}$ & 0.999999395 & 0.99999374 & $\begin{array}{c}6.051 \\
\mathrm{E}-07\end{array}$ & $\begin{array}{c}6.05104 \\
\mathrm{E}-07\end{array}$ & $\begin{array}{c}6.86478 \\
\mathrm{E}-06\end{array}$ \\
\hline $13-\mathrm{Apr}$ & 12.5 & 1029 & 1006437924 & $\begin{array}{c}1.02242 \\
\mathrm{E}-06\end{array}$ & 0.999998978 & 0.999993135 & $\begin{array}{c}1.02241 \\
\mathrm{E}-06\end{array}$ & $\begin{array}{c}1.02242 \\
\mathrm{E}-06\end{array}$ & $\begin{array}{c}7.8872 \\
\mathrm{E}-06\end{array}$ \\
\hline 14-Apr & 13.5 & 966 & 1006436895 & $\begin{array}{c}9.59822 \\
\mathrm{E}-07\end{array}$ & 0.99999904 & 0.999992113 & $\begin{array}{c}9.59814 \\
\mathrm{E}-07\end{array}$ & $\begin{array}{c}9.59822 \\
\mathrm{E}-07\end{array}$ & $\begin{array}{c}8.84702 \\
\mathrm{E}-06\end{array}$ \\
\hline 15-Apr & 14.5 & 990 & 1006435929 & $\begin{array}{c}9.83669 \\
\mathrm{E}-07\end{array}$ & 0.999999016 & 0.999991153 & $\begin{array}{c}9.8366 \\
\mathrm{E}-07\end{array}$ & $\begin{array}{c}9.8367 \\
\mathrm{E}-07\end{array}$ & $\begin{array}{c}9.83069 \\
\mathrm{E}-06\end{array}$ \\
\hline 16-Apr & 15.5 & 1284 & 1006434939 & $\begin{array}{c}1.27579 \\
\mathrm{E}-06\end{array}$ & 0.999998724 & 0.999990169 & $\begin{array}{c}1.27578 \\
\mathrm{E}-06\end{array}$ & $\begin{array}{c}1.27579 \\
\mathrm{E}-06\end{array}$ & $\begin{array}{c}1.11065 \\
\mathrm{E}-05\end{array}$ \\
\hline 17-Apr & 16.5 & 1517 & 1006433655 & $\begin{array}{c}1.5073 \\
\mathrm{E}-06\end{array}$ & 0.999998493 & 0.999988894 & $\begin{array}{c}1.50729 \\
\mathrm{E}-06\end{array}$ & $\begin{array}{c}1.5073 \\
\mathrm{E}-06\end{array}$ & $\begin{array}{c}1.26138 \\
\mathrm{E}-05\end{array}$ \\
\hline 18-Apr & 17.5 & 2267 & 1006432138 & $\begin{array}{c}2.25251 \\
\mathrm{E}-06\end{array}$ & 0.999997747 & 0.999987386 & $\begin{array}{c}2.25248 \\
\mathrm{E}-06\end{array}$ & $\begin{array}{c}2.25251 \\
\mathrm{E}-06\end{array}$ & $\begin{array}{c}1.48663 \\
\mathrm{E}-05\end{array}$ \\
\hline 19-Apr & 18.5 & 1250 & 1006429871 & $\begin{array}{c}1.24201 \\
\mathrm{E}-06\end{array}$ & 0.999998758 & 0.999985134 & $\begin{array}{c}1.242 \\
\mathrm{E}-06\end{array}$ & $\begin{array}{c}1.24201 \\
\mathrm{E}-06\end{array}$ & $\begin{array}{c}1.61083 \\
\mathrm{E}-05\end{array}$ \\
\hline
\end{tabular}

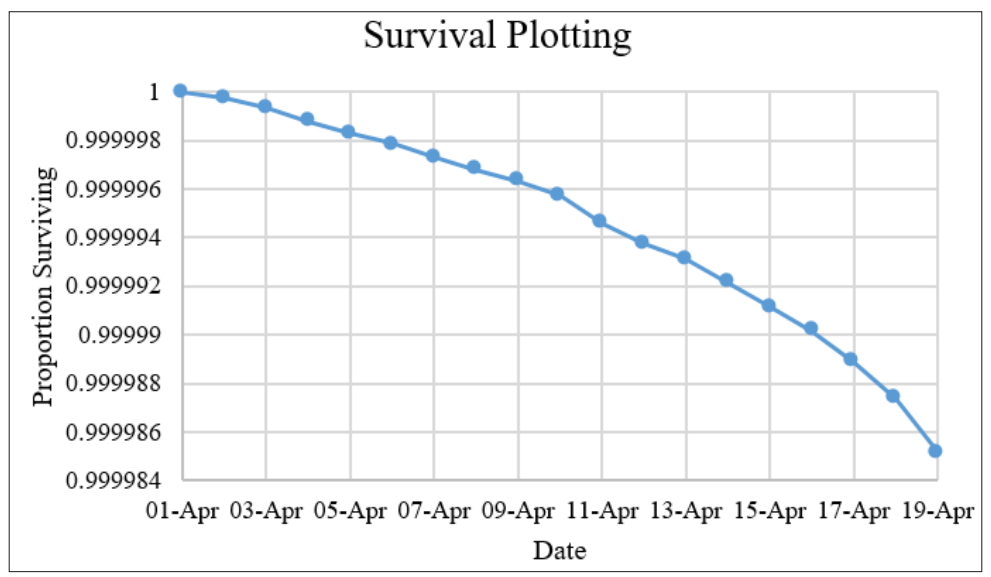

Figure 5.Survival plot from clinical life table

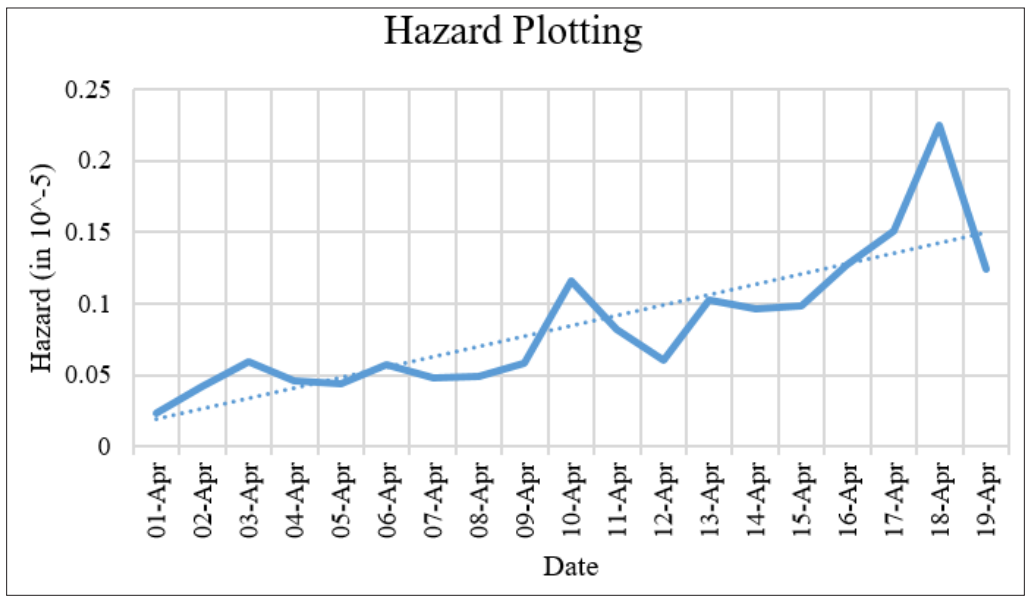

Figure 6.Hazard plot from clinical life table 


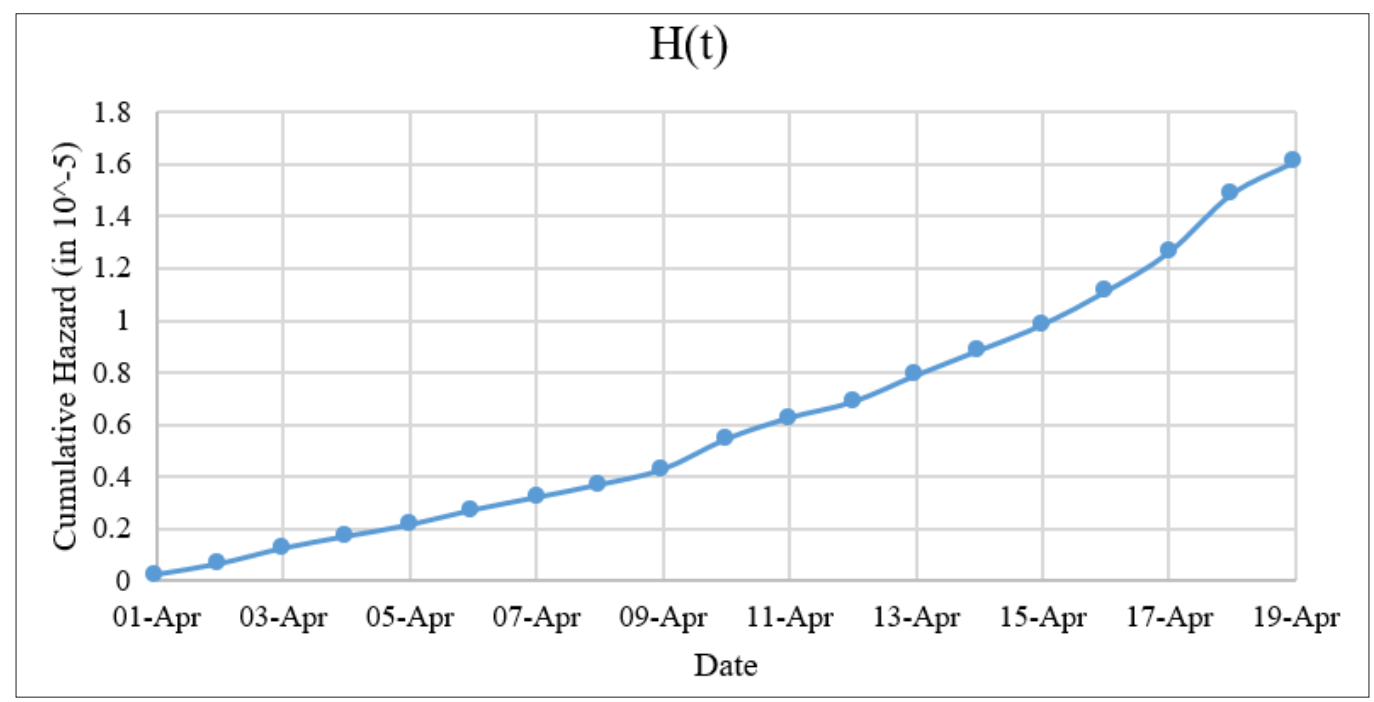

Figure 7.Cumulative hazard plot from clinical life table

Table 5.Cure fraction models

Exponential Mixture Cure Model

\begin{tabular}{|c|c|c|c|c|c|} 
& Mean & SD & MC_error & Median & DIC \\
\hline$\lambda$ & 0.003671 & 0.01174 & 0.002024 & $6.14 \mathrm{E}-04$ & 370.2 \\
\hline $\mathrm{C}$ & 0.99812 & 0.02628 & 0.004209 & 0.9803 & \\
\hline
\end{tabular}

Exponential Non- Mixture Cure Model

\begin{tabular}{|c|c|c|c|c|c|}
\hline & Mean & SD & MC_error & Median & DIC \\
\hline$\lambda$ & 0.003329 & 0.01181 & 0.002037 & $5.20 \mathrm{E}-04$ & 372.0 \\
\hline C & 0.9579 & 0.02944 & 0.004926 & 0.9753 & \\
\hline
\end{tabular}

Gamma Mixture Cure Model

\begin{tabular}{|c|c|c|c|c|c|}
\hline & Mean & SD & MC_error & Median & DIC \\
\hline$Y$ & 2.04 & 0.1183 & 0.01262 & 2.048 & 401.3 \\
\hline C & 0.9937 & 0.05523 & 0.005395 & 0.9992 & \\
\hline
\end{tabular}

Gamma Non- Mixture Cure Model

\begin{tabular}{|c|c|c|c|c|c|}
\hline & Mean & SD & MC_error & Median & DIC \\
\hline$\Gamma$ & 0.001989 & 0.01649 & 0.001544 & $2.37 \mathrm{E}-04$ & 414.8 \\
\hline $\mathrm{C}$ & 0.9831 & 0.009568 & 0.001048 & 0.9972 & \\
\hline
\end{tabular}

Weibull Mixture Cure Model

\begin{tabular}{|c|c|c|c|c|c|}
\hline & Mean & SD & MC_error & Median & DIC \\
\hline$\alpha$ & 0.02301 & 0.1501 & 0.01328 & 0.003975 & 393.0 \\
\hline Y & 0.08431 & 0.06585 & 0.007913 & 0.1008 & \\
\hline$C$ & 0.1953 & 0.09628 & 0.01665 & 0.2325 & \\
\hline
\end{tabular}

Weibull Non- Mixture Cure Model

\begin{tabular}{|c|c|c|c|c|c|}
\hline & mean & SD & MC_error & Median & DIC \\
\hline$\alpha$ & 0.002857 & 0.02225 & 0.002316 & $5.51 \mathrm{E}-04$ & 396.9 \\
\hline$\gamma$ & 0.1274 & 0.07803 & 0.01057 & 0.1582 & \\
\hline$C$ & 0.97815 & 0.01977 & 0.00810 & 0.98375 & \\
\hline
\end{tabular}


Define event of interest as "onset of COVID-19" with baseline as 1 April 2020 for general population then the survival time for each individual will be "COVID-19 free survival". As mentioned earlier, the observation period of this study is first 19 days of April month. So, keeping in mind the highly contagious nature of disease if we assume that those who are COVID free during this period are longterm survivors. We simulated one million data points to get survival times, on applying mixture and non-mixture cure fraction model using Open BUGS software package we get the following results (Table 5). From table the model that gives least DIC value is exponential mixture cure model with DIC value of 370.2 and cure fraction 0.99812, i.e. after 19 days of pandemic (base shifted to 1 April) around $99.812 \%$ of general population will be COVID-19 free.

\section{Conclusion}

Without thorough study, temporary measures like contentious blanket lockdown the resulting slowing down of economy is inevitable. Due to this COVID-19 menace, global giant economies are at cusp of following the rocky path ahead.

To mitigate the repercussions of COVID-19 containment, strategist should prepare the plan at micro level amidst pandemic.

Currently Government of India is segregating Districts in red, yellow and green zones. Here we suggest to augment the plan for red zone Districts. There should be different cluster containment plans for various Districts that falls into red zone. Each District ought to have plan based on clinical life table for general population. Life table must be fed with data pertaining to migration of people to/ from the District, birth, death due to natural causes, death due to other diseases, death due to accidents.

If provided data on proper COVID-19 free survival for each District then probabilistic models like cure fraction can be used to find proportion of long-term survivors in foreseeable future that would be helpful in planning.

\section{Conflict of Interest: None}

\section{References}

1. Gupta N, Praharaj I, Bhatnagar T et al. Severe acute respiratory illness surveillance for coronavirus disease 2019, India, 2020. Indian Journal of Medical Research 2020; 151(2): 236.

2. Mazumder A, Arora M, Bharadiya V et al. SARS-CoV-2 epidemic in India: epidemiological features and in silico analysis of the effect of interventions. F1000Research 2020; 9(315): 315.

3. World Health Organization. Coronavirus disease 2019 (COVID-19) Situation Report - 91. Available from: https://www.who.int/docs/default-source/ coronaviruse/situation-reports/20200420-sitrep-91covid-19.pdf?sfursn=fcf0670b_4. Accessed on May 05, 2020.

4. Indian Council of Medical Research. Strategy of COVID19 testing in India (17/03/2020). New Delhi: ICMR; 2020. Available from: https://main.icmr.nic.in/sites/default/ files/upload_documents/Strategey_for_COVID19 Test_v4_09042020.pdf. Accessed on April 24, 2020.

5. Ng HP, Ong SH, Foong KW et al. Medical image segmentation using $\mathrm{k}$-means clustering and improved watershed algorithm. IEEE Southwest Symposium on Image Analysis and Interpretation 2006; 61-65.

6. Selvan AN, Cole LM, Spackman L et al. Hierarchical cluster analysis to aid diagnostic image data visualization of MS and other medical imaging modalities. Imaging Mass Spectrometry, Humana Press, New York, NY. 2017; 95-123.

7. Ferguson JG. Life tables for clinical scientists. Journal of Vascular and Interventional Radiology 1992; 3(4): 607-15.

8. Grover G, Das D. On the construction of clinical life table for studying the survivability of diagnosed AIDS cases. The Journal of Communicable Diseases 2005; 37(3): 165-172.

9. Lee ET, Wang J. Statistical methods for survival data analysis. John Wiley \& Sons, 2003.

10. Berkson J, Gage RP. Survival curve for cancer patients following treatment. Journal of the American Statistical Association 1952; 47(259): 501-15.

11. Farewell VT. The use of mixture models for the analysis of survival data with long-term survivors. Biometrics 1982; 1041-6.

12. Yamaguchi K. Accelerated failure-time regression models with a regression model of surviving fraction: an application to the analysis of "permanent employment" in Japan. Journal of the American Statistical Association 1992; 87(418): 284-292.

13. Maller RA, Zhou S. Testing for the presence of immune or cured individuals in censored survival data. Biometrics 1995; 1197-205.

14. Chen MH, Ibrahim JG, Sinha D. A new Bayesian model for survival data with a surviving fraction. Journal of the American Statistical Association 1999; 94(447): 909-19.

15. Peng $Y$, Dear KB. A nonparametric mixture model for cure rate estimation. Biometrics 2000; 56(1): 237-43.

16. Kannan N, Kundu D, Nair P et al. The generalized exponential cure rate model with covariates. Journal of Applied Statistics 2010; 37(10): 1625-36.

17. Varshney MK, Grover G, Ravi V et al. Cure fraction model for the estimation of long-term survivors of HIV/ AIDS patients under antiretroviral therapy. $J$ Commun Dis 2018; 50(3).

18. Grover G, Thakur AK, Garg B. Cure fraction estimation 
for traumatic lumbar puncture in patients with acute lymphoblastic leukemia. Research \& Reviews: Journal of Oncology and Hematology 2019; 7(3): 12-21.

19. Achcar JA, Coelho-Barros EA, Mazucheli J. Cure fraction models using mixture and non-mixture models. Tatra Mountains Mathematical Publications 2012; 51(1): 1-9. 